\title{
The Theory of Legal Education of Non-legal Profession in Colleges and Universities
}

\author{
Fan Daoyan, Khalmakshinova Svetlana \\ School of Humanities and Law, Northeastern University, Shenyang, China \\ Email address: \\ fandaoyan0413@qq.com (F. Daoyan), svetulka0507@mail.ru (K. Svetlana) \\ To cite this article: \\ Fan Daoyan, Khalmakshinova Svetlana. The Theory of Legal Education of Non-legal Profession in Colleges and Universities. Education \\ Journal. Vol. 5, No. 6, 2016, pp. 183-187. doi: 10.11648/j.edu.20160506.19
}

Received: November 15, 2016; Accepted: December 28, 2016; Published: December 30, 2016

\begin{abstract}
It is necessary to strengthen the legal education of the non-legal majors in colleges and universities, to build Socialist country under the rule of law, to improve the comprehensive ability and quality of college students and to create a good campus environment. At present, the legal education of the non-legal profession in colleges and universities has the misunderstanding of the target of "compulsory education of law", the popularization of "popularizing legal education" and the poor teaching effect of "professional law". It is necessary to perfect the legal education of the non-legal profession in colleges and universities, to highlight the independence of the legal education of the non-legal profession, to strengthen the practical effect of the legal education popularization of the non-legal profession, to improve the educational law of the specialized law course, to make full use of the law department education resources.
\end{abstract}

Keywords: Non-legal Profession in Colleges, Lawful Education, Compulsory Education of Law

\section{Introduction}

During the period between the 1980s and now, the number of Chinese universities which offer law course has increased by 100 times, even though it still can not compare with the number of Chinese college students. The fact has aroused great concern for legal profession students. However, there is few pubic concern for non-legal students. After The fourth Plenary Session of the 18th CPC Central Committee, China has accelerated the pace of a country ruled by law. Constructing a nation ruled by law, not only elites of law, but improving the consciousness nomocracy, popularizating of legal knowledge is necessary. As the future driving-force of the society construction, the university students play a leading role in promoting democracy and juridification. But Attention focused on legal education of non-legal profession students is absent, which is incoordinate with the pace of the construction of the rule of law in China. For a long time, the legal education of non-legal majors has not gained the adequate attention it deserves in universities [1]. The legal education of non-legal majors is diferent from that of legal majors in training objectives, teaching methods, and teaching objects, which deserves our full consideration. Because higher education emphasizes quality education and applied talents cultivation, legal education of non-legal majors should play important role in it. Legal education of the non-legal profession can strengthen students from the legal point of view of the profession, from a legal point of view of society. Not only to deepen students' understanding of the areas of professional knowledge of the laws and regulations to improve the professional quality of students and theoretical knowledge, But also conducive to the accurate positioning of the university personnel training programs and talent specifications, so that colleges and universities to further clarify the professional teaching objectives, educational features and other aspects of positioning.

\section{The Necessity of Legal Education of Non-legal Profession}

\subsection{The Requirement of Building Constitutional State in the Frame of Socialism}

Since the 15th National Congress of the Communist Party of China (CPC) put forward the basic strategy of running the country according to law, China has gradually pushed on a process of it, especially after the 18th National Congress of the Communist Party of China, the process of building a socialist 
constitutional country has become more and more faster, and in economic, political, culture and other fields started to develop in all directions. Under the condition of running the country according to law and economy of the market, legal regulation and legal protection permeated to all fields of social life in all directions, and had the corresponding legal quality requirements for all social members in all industries. The building of constitutional society can't be accomplished by only a few law elite who comprehend a concept of running the country according to law; it requires the increasing of legal quality and legal awareness of all the citizens. Undergraduates are the object of this concept pf legal system education, but also are the proponents of this concept [2]. They bear the major responsibility of social construction. Therefore, strengthening education of the legal system is the basic condition of power, democratic constitutional country.

\subsection{The Requirement of Improving the Comprehensive Ability and Literacy Quality of College Students}

In China's education, since the 1980s put forward the concept of quality education, whether in the field of basic education or in the field of higher education, practice quality education has become an irresistible trend, To promote the comprehensive development of students, and comprehensively improve the overall quality of students is the ultimate goal of educators. Comprehensive ability and literacy quality of students except solid professional knowledge should also be embodied in the moral, psychological, legal system. College students had an effect of the influence of the traditional Chinese concept of "rule by man", college students lack traditional consciousness of democracy and legal system. Nowadays, higher education in China attaches great importance to moral and psychological education. In addition to setting up ideological and political education, each university has a special psychological consultation institution. But only non-legal legal education is lacking of politics education, there is no special structure of legal education institutions. These non-legal students only stay in the "ideological and moral cultivation and basis of law", students of law students cannot really understand the true meaning of the content and importance of the last two chapters of this course. This educational status this kind of education leads to the students who are not majoring in law have relatively solid professional knowledge, but lack of the necessary rule of law and basic knowledge of law, which makes them lack of the consciousness of rule by law when they participate in the economic activities of market called "nature is the rule of law economy". This becomes an important factor of affecting their comprehensive ability and quality.

\subsection{The Requirement of Developing Education}

In recent years, a few criminal offence in universities has occurred [3]. Although the reason is diversification, the lacking of legal knowledge is one of the greatest sources. Xinhua News Agency, the Legal Evening News has published an article of survey shows that poor college students crime rate is slow growth, half of the criminals are illiterate. The report said that after the survey found that more than half of college students motive is very naive, they grew up in the formation of personality defects and blind consciousness led them to commit a crime. Therefore, it is necessary to emphasize the legal education of non-legal students and strengthen law consciousness, which is also the requirement of developing education. In the past 30 years, under the guidance of the theory of democracy and legal system construction and the theory of 'ruling the country according to law', China has made unprecedented achievements in the construction of educational legal system. The achievements of educational legislation has become a powerful guarantee for the development of education in China. The National People's Congress and its Standing Committee have enacted and promulgated a number of educational administrative regulations. For example, Compulsory Education Law, Academic Rule and so on. Local governments have enacted local laws and regulations, including the implementation of the national education law, compulsory education investment regulations, the campus protection regulations and other local laws and regulations. Strengthen the legal awareness of college students, can make them aware of the protection of national laws and regulations, can make them fully aware that only the establishment of a sound education legal regulations can effectively safeguard the legitimate rights and interests of all sectors of society, and It allows them to have the right legal literacy, positive and healthy way of thinking, in case of distress, doing things can often think from the legal point of view, and gradually develop the habit of rational thinking, in accordance with the requirements and norms of law constraints of their words and deeds.

\section{The Legal Education of Unlawful Major in Colleges and Universities of Our Country and Its Present Situation}

\subsection{Deviation of Educational Objectives in the Course of Jurisprudence Education}

According to the requirements of the Ministry of Education, the curriculum 'legal basis' and 'ideological and moral cultivation' into the course 'ideological and moral cultivation and legal basis' [4], all college students must learn compulsory public basic course, so the last two chapters Basic 'part of the illegal students is the law required course'. It shows there is a few mistake, specifically in two aspects: First, the level of education goals dislocation. The legal basis and ideological and moral cultivation as a course, this education is the national political needs, compared with the previous "Legal Foundation" courses, the content of the law significantly reduced, only two chapters related to the simple Legal knowledge and political color is stronger than the legal knowledge of the "socialist concept of the rule of law" [5]. This kind of setting is obviously the integration of morality and law, the rule of legal education into the scope of moral education, the rule of legal education 
services in moral education, the legal education in the level of education on the level of dislocation, the independence of legal education submerged in the moral The general nature of education. Second, the deviation of the connotation of legal education objectives of non-legal profession. According to the Central Propaganda Department, the Ministry of Education requirements of the relevant documents, its teaching objectives should be based on the law of cognitive education [6]. Legal cognition refers to the overall feeling and consciousness of the social subject to the social legal culture, the legal norm system and the legal phenomenon essence. That is to say, the object of cognition is not only a simple interpretation and memorization of legal provisions and legal concepts, but a complex, internal structure and laws which contain legal culture, legal norms, legal phenomena and essence. The Systems of knowledge and skills. But in reality, the teachers of "ideological and moral cultivation and legal basis" in colleges and universities (in practice, there are few teachers of law profession) will mostly stay in the most shallow level of "knowledge" of legal cognitive education, The real grasp from the overall legal awareness of the teaching of the content of this goal. This will inevitably ignore the law students for the nature of the legal understanding and awareness of the legal training can not be completed by the legal awareness to the legal practice of change, it is difficult to develop legal habits.

\subsection{The Legal Education for the Non-legal Students Are Formality}

The legal education for non-legal students is mainly conducted in the form of elective courses or legal publicity within the campus. The elective course is a learning model which choose courses and learning each other between liberal arts and sciences. This form of course is a lot of people, when the person is little more than 100 people and sometimes more than 200 people, but there was no practical effect. It's making legal education for non-legal students become formalized. First, the attitude of Instructors and students are misconducted. The main purpose of most teachers is teaching work, and the students aims to get elective credits. Thus the teacher does not focus on classroom teaching, they just need someone to come to class. Students are also not concern about what can be learned, but get the credits. The situation for the elective system are devastating [7]. Second, the school of the monitoring mechanism is weak, can't form a substantial constraints to teachers and students. The courses are arranged in the weekend or at night, therefore there is no substantial monitoring, The instructors level of teaching is uneven and rarely use effective ways to control teaching, Eventually making the course formality and difficult to achieve the due effect. Instead, become the students drilled education system vulnerability of crack and make them more lazy.

\subsection{The Curricula of Legal Education in Non-law Profession Don't Have Deficient Effect}

With the continuous improvement of legislation, the role of the law has long been deep into the economic management, intellectual property, information, construction, energy, biochemistry and other fields. Therefore, colleges and universities set some curriculum to non-law students in accordance with the development of professional guidance documents and professional curriculum requirements of the corresponding law courses. However, these "professional jurisprudence" courses for non-law students fail to achieve the desired results, for the following reasons: First, most of the "professional law" courses of the non-law major are listed as Limit elective courses or optional elective courses, But because of teachers and other reasons, some of these courses only statically stay in the training program and teaching plan schedule. Secondly, due to the lack of in-depth study and analysis on the training objectives of the non-legal professional legal education, the curriculum lacks clear teaching guiding ideology, which is basically grasped freely by the teachers [8]. In the teaching method and teaching content, of the application of capacity as the main teaching objectives, the lack of law students of law on the application of the ability and vocational skills training, it is difficult to really play the legal quality and practical ability to train the effect. Thirdly, the "professional law" courses of the non-law major are usually held by the teachers of the law department, and the teaching teachers often rely on their professional teaching habit. In order to teach students according to their aptitude, the students who are lacking the general theory of law often feel confused. And would like to learn more in depth without their doors, and ultimately difficult to achieve good teaching results, these illegal professional "professional law" courses are more likely to become the school legal education tasteless. It is precisely because of the above reasons, universities for non-lawful students of legal education is difficult to play its due role, not even non-lawful students to build the lowest level of behavioral bottom line and psychological line of defense. For those who embarked on the society, the technical talents "eat the legal loss" or the illegal responsibility even jail in prison reality, the lack of legal education in colleges and universities to blame.

\subsection{The Teachers of Legal Education in Non-law Profession Are Lacking}

At present, some colleges and universities do not have law schools, and no law department. Experts in various fields, scholars, the original lack. Know the industry laws and regulations of experts, scholars are stretched. It is means, the shortage of teaching staff is also a major bottleneck which restricts the legal education of non-legal major in colleges and universities. This part of the university legal education teachers are not the majority of the legal profession, their basic theoretical knowledge of many legal issues and theoretical understanding is still shallow, and their lack of industry experience, practical experience, and the legal basis. These teachers lack teaching experience and teaching methods. In addition, their teaching methods only require students to understand and recite the legal provisions, most students only know the literal meaning, so it is difficult to achieve the purpose of cultivating college students legal awareness of the industry. 


\section{Suggestions on Perfecting the Legal Education of the Non-legal Profession in Colleges and Universities}

\subsection{Highlight the Independence of the Legal Education of Non-law Professional}

The law is relatively independent. Although law and morality have a natural relationship, but law and morality belong to two distinct evaluation system. Although the law is also guided by moral and reflects a reasonable moral appeal, but the law once established, and the moral rules of the separation is not subject to the interference of moral rules. Morality emphasizes the regulation of the individual through the evaluation of public opinion, while the law emphasizes the regulation of the external behavior of the individual through the coercive power of the ruling class. The function of the law is guaranteed by the state's coercive power and can not be replaced by the moral function. Therefore, the relativity of law requires legal education to be relatively independent of moral education. Law is only the lowest level of moral requirements, legal education should have its relatively independent cognitive basis and path choice, should follow the legal education from the cognitive to the emotional, from the will to the behavior of the progressive process of this educational law. The legal education should be separated from the dependence of moral education, and the legal effect of law should be highlighted in the case of the general weakening of the legal behavior of college students who are not majoring in law. In the long term, the current legal education for college students, especially those who are not majoring in law, should be listed out from the "ideological and moral cultivation and legal basis", and enrich the content and weight of legal education, and cultivate students' legal literacy and popularize law know how.

\subsection{Improving the Problem of Legal Education in the Non-legal Profession}

As mentioned above, the legal education within the university is a superficial form of law. In order to acquire the necessary basic legal knowledge for the non-law major students, and gradually improve their legal awareness, and ultimately affect their own of the behavior, we must enhance the effectiveness of the teaching of law elective course. Specifically to talk about this issue. First, the teacher's qualifications to be strict requirements. The college should have a macroscopic control over the professional title and teaching ability of the teachers who set up the courses. Adjunct professors, professors and lecturers with good teaching effect should be encouraged to open more law elective courses and prohibit teaching assistant. Second, educational administration should strengthen management. Such as teaching content, teaching objectives, teaching the overall design review. And implement the responsibility system at different levels. Thus, if the teaching effect of a legal education course is poor, or teaching content and process arose problems. Not only the teachers themselves to be responsible for the class, but also leaders and head of the teaching and research section in the school who initially approved the course should be responsible for the corresponding oversight fault. As a result, they can not sign their names freely on the file of reviewing the agreement to open this course. It is lack of regulation due to public elective classes on weekends or evenings. Should be set to supervise the teaching of public elective order. Resolutely put an end to arbitrarily exchange courses, the absence of teachers and undue delay to the next. For attendance is not up to low public elective course, should promptly notify the instructor to take appropriate measures. And can be taken in the next cycle of teaching restrictions, to prohibit the reopening of elective courses or to prohibit the creation of the same public courses. For the cumulative number of students who are no reason not to class, instructors should be strictly in accordance with the relevant provisions of educational administration to cancel their qualifications, or give them failing grades. Only in this way can we rectify the bad attitude of teachers to open law elective courses and bad motives of students choose the law elective courses, to ensure that out of the public elective law to achieve the desired effect. The legal evaluation of colleges and universities can further clarify the rights and obligations of students and universities, so that colleges and universities have more rights, students have more freedom of life and learning, and s can further clarify the law concepts 'National Compulsory' 'national willing' and 'normative' [9], also can guide students to pursue real fairness and justice, honesty and trustworthiness and unity of knowledge and action.

\subsection{Strengthening the Effectiveness of Legal Education Popularization in Non-legal}

First of all, for the setting up of law course in unlawful major, we should give full consideration to the relationship between professional courses and law courses, according to professional courses and the link between the law curriculum arrangements for teaching plans, the allocation of hours and credits. In the teaching content design of the law course, we should highlight the practical application characteristics. At the same time, we should always put the basic principles of law theory into teaching in the course of teaching law to them, in view of the lack of basic law theory of law students. Then, we should pay attention to the training of teachers in this course, and strengthen the communication between non-law teachers and law teachers. For the law courses of the non-legal profession, in fact, there are many industry norms, professional skills and its corresponding legal system. So it requires the teachers to have both a certain degree of professional knowledge and profound legal background. In addition, in view of the large number of non-professional law teachers from law schools, and the lack of communication and collaboration between them and faculty of specialized courses, we should be the purpose of creating opportunities for cooperation and exchange between the legal profession and the professional teachers of illegal law, therefore the perfect combination of the both, avoid the conflict in the teaching 
arrangements and schedule of them [10]. Finally, in the specific teaching methods, there are two kinds of wrong understanding need to be corrected: First, professional law courses can only be traditionally taught; the second is the professional law teaching is the interpretation of specific legal provisions. As a matter of fact, the methods used in teaching specialized law is also applicable to the education of the rule of law for non-legal students. Such as case analysis, group discussions, clinic education and other teaching methods. At the same time, in addition to the interpretation of the specific legal provisions, the same should also be included in their teaching content, for example, the corresponding legislative background, the corresponding social hot issues and so on.

\subsection{Perfecting the Textbook of Legal Education in the Non-legal Profession}

The quality of teaching materials is the key to the success or failure of law education. The legal course of the non-legal major is not only for the students 'professional knowledge, but also for the expansion of students' quality service, and the training of applied talents. The compilation of teaching materials should be compatible with this target. First, it must be closely linked to professionalism. It requires the editor to the practice department to conduct in-depth research that the professional generally encountered what the basic legal issues, which more prominent issues, in order to do legal courses closely integrated with the professional, theory and practice closely linked to such a legal textbook can really adapt to the needs of application-oriented personnel training. Second, there should be experts in the industry and the legal background of the experts to participate. On the one hand, the nature of textbook is a legal textbook, and the legal experts on legal understanding and recognition certainly not the same as non-professionals, so that legal textbook will not leave the track of law. On the other hand, the professional experts to participate in the preparation of legal textbook, which can be achieved very closely to achieve the goal of professionalism, and they can correctly understand the height of this course in the entire personnel training system from the professional personnel training. So that the textbook is more in line with the professional reality, the practicality of textbook will be protected, and the course of the industry characteristics are fully reflected. Otherwise, there is no need to work hard to re-compile another kind of textbook.

\section{Conclusion}

Legal education of non-legal profession is obviously different from legal professional education. It is not devoted to the education of legal professionals, but should belong to the higher level of civic quality education. At present, under the premise of the general lack of citizens 'legal consciousness, the legal awareness of college students is far from enough. However, as the main force of social construction, university students' legal literacy is directly related to China's democratization. It also highlights the effect of the mechanism on society, rule of law, democracy, good governance and human security in general. So the university of China's illegal law students of legal education is of great significance. However, there are still some shortcomings in practice, such as deviation of educational objectives in the course of jurisprudence education, the legal education for the non-legal students are formality and ineffectiveness of curriculum. Corresponding to these shortcomings, we made a few suggestions: highlight the independence of the legal education of non-law professional, strengthening the effectiveness and improving the problem of legal education popularization in non - legal. In short, non-legal profession's legal education is still a long way to go, should pay attention to and be perfected in China.

\section{References}

[1] B. Chen. On Legal Education of Unlawful Major in Colleges and Universities [J]. Journal of Capital Normal University (Social Sciences Edition), 2014, (06).

[2] H. Wang. On the political conditions of democracy [J]. OF HUAQIAO UNIVERSITY (PHILOSOPHY \& SOCIAL Science Edition), 2016, (04).

[3] M. Chen. Limitation and Transcendence of Law [M]. Chengdu: Sichuan people publishing. 2013.

[4] [EB/OL]http://gaokao.xdf.cn/201404/9967246.html.

[5] B. Tan. On the perfection of the legal education of the non-legal profession in universities of science and engineering [J]. Citizen and Law, 2016, (07).

[6] X. Zhang. Reshaping of the goal of jurisprudence education of non-legal profession in colleges and universities [J]. Langfang division Journal of Hunan University of Science and Technology, 2011, (03).

[7] J. Wei, Dong Jie. Cognition, Idea and Belief: Three Dimensions of Legal Education and Its Convergence mechanism [J]. Ideological and Political Education Research, 2015, (05).

[8] B. Wang, Wang Bei. A Study on the Objective of Cultivating the Comprehensive Quality of Innovative Law Undergraduates [J]. Journal of Liaoning Administration Institute, 2015, (12).

[9] T. Ma. A Brief Discussion on Some Problems of Law Teaching in non-legal Undergraduate Major [J]. Jiangsu Province Journal of Technical Teachers College, 2016, (05).

[10] [EB/OL] http://edu.qq.com/a/20090310/000103.him. 